ENTREPRENEURSHIP AND SUSTAINABILITY ISSUES

ISSN 2345-0282 (online) http://jssidoi.org/jesi/

2020 Volume 7 Number 3 (March)

http://doi.org/10.9770/jesi.2020.7.3(39)

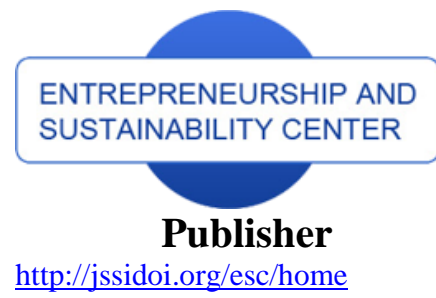

http://jssidoi.org/esc/home
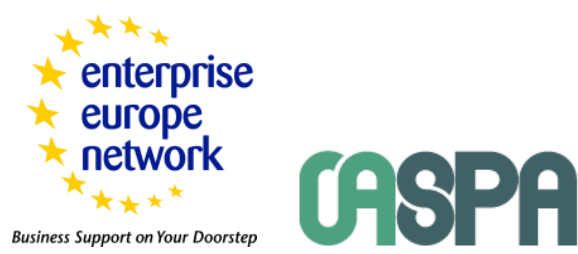

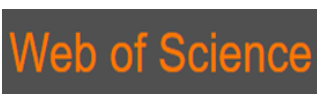

1) Clarivate

Analytics

\title{
"THE RELATION BETWEEN AGING OF POPULATION AND SUSTAINABLE DEVELOPMENT OF EU COUNTRIES
}

\author{
Ieva Meidutè-Kavaliauskienè $\dot{1}^{1}$, Gitana Dudzevičiūte் ${ }^{2}$, Nijolė Maknickiené $\dot{3}^{3}$, Aidas Vasilis Vasiliauskas ${ }^{4}$ \\ 1,2, 4 General Jonas Zemaitis Military Academy of Lithuania, Silo str. 5A, Vilnius, Lithuania \\ ${ }^{3}$ Business management faculty, Vilnius Gediminas Technical University, Sauletekio al. 11, Vilnius, Lithuania
}

E-mails: ieva.meidute@lka.lt ; ${ }^{2}$ gitana.dudzeviciute@lka.lt ; ${ }^{3}$ nijole.maknickiene@vgtu.lt $;{ }^{4}$ aidas.vasilisvasiliauskas@lka.lt

Received 16 October 2019; accepted 18 December 2019; published 30 March 2020

\begin{abstract}
Sustainable development is based on the idea of achieving an acceptable level of social, economic, and cultural development. However, there are a lot of impediments to achieving this idea so far. Population aging is one of these (and, probably, major) global trends affecting all countries and putting the realization of sustainable development goals at risk. The main goal of this article, therefore, is to test the relation between aging and three groups of indicators of sustainable development of EU countries. The investigation that forms the basis of the given article has focused on the median age of the population and six sustainable development indicators of the EU countries. The analysis covers annual data of the period from 2000 to 2018. All variables have been obtained from the Eurostat database. This has provided a possibility to compare the EU countries by indicators under consideration.
\end{abstract}

Keywords: sustainable development; sustainable development indicators; population ageing; EU regions

Reference to this paper should be made as follows: Meidutė-Kavaliauskienè, I., Dudzevičiūtè, G., Maknickienė, N., Vasilis Vasiliauskas, A. 2020. The relation between aging of population and sustainable development of EU countries. Entrepreneurship and Sustainability Issues, 7(3), 2026-2042. https://doi.org/10.9770/jesi.2020.7.3(39)

JEL Classifications: J00, J11, J19

\section{Introduction}

In the studies of international organizations (United Nations et al., 2003), three approaches to sustainable development have prevailed, as follows: 1) the first approach considers sustainable development as economic, social and environmental systems, all of which must be simultaneously sustainable; 2) the second approach is ecosystem health, which views the economic and social systems as subsystems of the global environment. This approach is focused on the pressures placed on ecosystems by human activities; 3) the third approach is related to resources or capital and views sustainable development as development ensuring non-declining per capita national wealth by conserving or replacing the stocks of produced human, social and natural capital.

\footnotetext{
* This work was partially supported by the Ministry of National Defence of the Republic of Lithuania
} 


\section{ENTREPRENEURSHIP AND SUSTAINABILITY ISSUES}

ISSN 2345-0282 (online) http://jssidoi.org/jesi/

2020 Volume 7 Number 3 (March)

http://doi.org/10.9770/jesi.2020.7.3(39)

While economists have been contributing to the discussion of various aspects of sustainability, it is notable that the term "sustainability economics" does not refer to any explicit definition, and is not obviously joined by the characteristics, such as subject focus, methodology, or institutional background (Baumgärtner, Quaas, 2010). Sustainability is not only a matter of acting in another way. It is creating another logic of economics. The science of economic needs to be grounded in understanding of economics and business activities and how this could be connected to sustainability (Clark, 2018). Sustainable economics requires a systemic approach first taking societal changes into consideration.

Tendencies in population aging are particularly relevant to the Sustainable Development Goals related to inequalities between and within countries, poverty, ensuring healthy lives and wellbeing at all ages, promoting gender equality and productive employment and making human settlements safe, inclusive, resilient and sustainable (United Nations, 2017). Population aging is a major global trend that affects all countries, at a different level (Dugarova, Gülasan, 2017; World Bank Group, 2016, United Nations, 2017).

The main question and, therefore, the goal of this article that the authors are rising is, if there are relations between aging and three groups of indicators of sustainable development of EU countries (and if yes, then, to what extent).

In order to answer this question, the article starts with an in-depth analysis of scientific literature associated with the topics of sustainability, population aging and indicators used to track and evaluate sustainable development from different perspectives. This is followed by Chapter 2, which discusses the methodology applied to conduct research and reasons why several key indicators of aging were chosen for further investigation. Chapter 3 , then, provides basic findings of the research related to aging and relations between aging and three groups of indicators of sustainable development of EU countries. The article ends with some investigation findings and discussion questions for further research in this important field.

\section{Literature review}

Concept of sustainability. The first and one of the most important conferences of the United Nations on the Human Environment was held in Stockholm, Sweden, in 1972, which presented initial conceptions regarding sustainable development. In 1987, The Brundtland Report was published propagating that sustainable development meets the needs of the present without compromising the ability of future generations to meet their needs (Brundtland Report, 1987; Nogueira, 2019).

In the last decade, the phenomenon of economy and the factors affecting its development got attention from a vast number of scientists all around the world (Cowell, 2013; Dudzevičiūtè, 2015; Chapple, Montero, 2016; Jiang et al., 2017; Atienza et al., 2018; Athukorala, Narayanan, 2018; Lihtmaa et al., 2018, Maknickiené et al., 2018, Dobrovolskiene, et al., 2019, Reis et al., 2019; Moumen et al., 2019; Estevaro et al., 2019; Mauerhofer, 2019, Baltgailis, 2019; Prakash, Garg, 2019; Vigliarolo, 2020; Pereira et al., 2020).

It should be noted that many of these scientists argue over the concept of a traditional and sustainable economy. (Bartelmus, 2010; Daniels, 2010; Todaro, Smith, 2011; Blum, Legey, 2012; Lund, Hvelplund, 2012; Binder, Witt, 2012; Birkin, Polesie, 2013; Lejano, Stokols, 2013; Stankevičienè et al., 2014; Vokoun, 2016; Nogueira, 2019; Bartley, 2019, Reis et al., 2019). In the work of Todaro and Smith (2011) three different attitudes towards the development of the economy are distinguished, i.e., traditional attitude, new economy attitude and Amartya Sen's attitude of "abilities". 


\section{ENTREPRENEURSHIP AND SUSTAINABILITY ISSUES}

ISSN 2345-0282 (online) http://jssidoi.org/jesi/ 2020 Volume 7 Number 3 (March)

http://doi.org/10.9770/jesi.2020.7.3(39)

The traditional attitude of economic development is based on the indicator of gross domestic product per capita, which clearly indicates the wellbeing of the society and the exact level of economic development. However, this indicator does not always represent a real situation, and, hence, sometimes is too narrow. This new attitude describes economic development as a multidimensional process encompassing a great number of activities of different institutions, aiming at economic growth, different decisions to increase social cohesion, distribution of resources in order to assure a better quality of life for the entire society (Todaro, Smith, 2011; Dudzevičiūtè, 2015).

In accordance to the Amartya Sen's attitude of "abilities", economic development should be directed towards the reinforcement of the sense of self-esteem and freedom. According to this attitude, economic development should eliminate all factors that prevent freedom and economic possibilities (Todaro, Smith, 2011). Binder and Witt (2012) argued if sustainable development can benefit from the synthesis with the Amartya Sen's attitude of "abilities" while obtaining firm normative background and wider application at the same time.

According to Remig (2015), the debate about sustainability economics has stimulated many of the contributions in the scientific literature. There is no application of the concept of sustainability economics in a specific context as there are many unclear aspects of what sustainability economics strives to and which underlying criteria will be chosen.

All in all, the concept of sustainable development is based on the evaluation of how decisions of the society in one of the fields - economy, social, and environmental - will impact the other two. In scientific articles, sustainable development (Bartelmus, 2010; Blum, Legey, 2012; Lund, Hvelplund, 2012; Stankevičienè et al., 2014; Vokoun, 2016; Maknickienè et al., 2018; Nogueira, 2019, Sarma et al., 2019; Reis et.al., 2019; Pereira et al., 2020) is analyzed in relation to different approaches: ecological sustainability of the resilience of ecosystems; economic sustainability of non-declining welfare, the notion of theoretical environmental economics; economic sustainability of economic performance and growth, using modified accounting indicators of produced and natural capital formation; and sustainability of development, which seeks to meet present and future needs of the society.

Goals and indicators of sustainable development. It is notable that the evolution of sustainable development concepts requires a shift toward a systemic and integrated perspective that facilitates the understanding of complexity (Liboni and Cezarino, 2014; Eustachio et al., 2019). In the scientific context, different views exist to assess the progress of sustainable development (Bell and Morse 2001). For example, the EU provides a list of sustainable development goals that are provided in Table 1.

Table 1. Sustainable development goals of the European Union

\begin{tabular}{|l|l|}
\hline \multicolumn{2}{|c|}{ Goals } \\
\hline No poverty & Zero hunger \\
\hline Good health and well-being & Quality education \\
\hline Gender equality & Clean water and sanitation \\
\hline Affordable and clean energy & Decent work and economic growth \\
\hline Industry innovation and infrastructure & Reduced inequalities \\
\hline Sustainable cities and communities & \\
\hline Climate action & Responsible consumption and production \\
\hline Life on land & Life below water \\
\hline Partnerships for the goals & Peace, justice, and strong institutions \\
\hline
\end{tabular}


ENTREPRENEURSHIP AND SUSTAINABILITY ISSUES

ISSN 2345-0282 (online) http://jssidoi.org/jesi/ 2020 Volume 7 Number 3 (March)

http://doi.org/10.9770/jesi.2020.7.3(39)

Source: Compiled by authors based on information from the Statistical Offices of the European Union (2018)

Eustachio et al. (2019) revealed 14 indicators for evaluating the sustainability. The relationship between sustainable development indicators and goals is presented in Table 2.

Table 2. Relationship between sustainable development indicators and goals

\begin{tabular}{|l|l|}
\hline \multicolumn{1}{|c|}{ Sustainable development indicators } & \multicolumn{1}{c|}{ Sustainable development goals } \\
\hline Infrastructure, health, and no hunger & Clean water and sanitation \\
& Good health and well-being \\
& Zero hunger \\
Affordable and clean energy & Partnerships for the goals \\
& Responsible consumption and production \\
Sustainable cities and communities & Gender equality \\
\hline Life on land and below water & Life on land \\
& Life below water \\
& Reduced inequalities \\
& Industry innovation and infrastructure \\
\hline Education & Quality education \\
\hline Economic growth & Decent work and economic growth \\
\hline Firm's corruption & Peace, justice, and strong institutions \\
\hline No poverty & No poverty \\
\hline Preservation of natural resources & Responsible consumption and production \\
\hline Clean energy and gender equality & Affordable and clean energy \\
& Gender equality \\
\hline International trade & Partnerships for the goals \\
\hline Industry activity & Industry innovation and infrastructure \\
\hline Peace and justice & Peace, justice, and strong institutions \\
\hline Employment, gender, and country equality & Gender equality \\
& Reduced inequalities \\
& Decent work and economic growth \\
\hline Growth rate in consumption and income & Reduced inequalities \\
\hline No air pollution & Sustainable cities and communities \\
\hline & Source: Eustachio et al. (2019) \\
\hline & \\
\hline
\end{tabular}

Efficient indicators, monitoring systems, and strong governance are needed for the countries seeking to become sustainable (Allen et al., 2017; Eustachio et al., 2019; Bartniczak, Raszkowski, 2019). However, despite the fact that the sustainable development indicators offered by international institutions, organizations, and scientists differ slightly, the focus while evaluating sustainable development should be on assessing economic, social, and environmental processes.

Relation between sustainable development and population aging. According to the World Health Organization (2015) and the United Nations (2017), the global strategy on aging will have an impact on the realization of the Sustainable Development Goals. The tendencies in population aging are particularly relevant to the Sustainable Development Goals related to inequalities between and within countries, poverty, ensuring healthy lives and wellbeing at all ages, promoting gender equality and productive employment and making human settlements safe, inclusive, resilient, and sustainable (United Nations, 2017). By 2050, the population over the age of 60 will double (World Health Organization, 2015). This demographic change is having a strong impact on sustainable development because as people grow older, their needs, health and what they value change accordingly. In 2015, older women tended to be more marginalized and disadvantaged than older men, showing higher rates of poverty among older women (United Nations, 2017). Chapman and Shigetomi (2018) investigated sustainable 


\section{ENTREPRENEURSHIP AND SUSTAINABILITY ISSUES}

ISSN 2345-0282 (online) http://jssidoi.org/jesi/

2020 Volume 7 Number 3 (March)

http://doi.org/10.9770/jesi.2020.7.3(39)

development by incorporating an approach to stakeholder engagement. The study assessed sustainability, identifying a gap in terms of the inclusion of the householder perceived importance of lifestyle-related factors in sustainable development policymaking. The investigation of householders was undertaken using a case study of the aging population of Japan, which demonstrated that lifestyle relevant factors of sustainability approximate jurisdictionally important Sustainable Development Goals of the United Nations. The authors assessed the importance of 6 general lifestyle factors, such as environmental protection, preserving limited resources, climate change, a healthy economy, a convenient lifestyle and equitable society. The case study of Japanese has revealed that the four factors like environmental protection, a healthy economy, preserving limited resources and equitable society, were the most important to respondents. Climate change was considered slightly less important and a convenient lifestyle was given the lowest priority of all. Moreover, the variety across household generations was identified. The investigation revealed that in general, older households place a higher priority on the environment, climate change issues, resource management, the economy, and social equity, while younger people place a higher priority on convenience. The research of Kiely et al. (2019) presented a broad narrative review of the epidemiological evidence on how the mental health of older adults varies by gender. The investigation revealed that compared to older men, older women are more likely to experience common mental disorders such as depression and anxiety. In contrast, mortality-related impacts of poor mental health are more severe in older men. The study of Leeson (2019) confirmed the relationship between increasing age and death. Besides, the research indicated large increases in home-based deaths, particularly for men aged 65 and over.

\section{Methodology}

The investigation that forms the basis of the given article has focused on the median age of the population and six sustainable development indicators of the EU countries. The analysis covers annual data for the period from 2000 to 2018. All variables have been obtained from the Eurostat database. It has provided a possibility to compare the EU countries by the indicators under consideration. Referring to the Eurostat (2019) information, we provide the descriptions of the indicators used in the research below.

The median age of a population is the age that divides this population into two numerically equal groups. It means that one half of people from this population are younger than the median age and the other half of them are older. The indicator of people at risk of poverty or social exclusion relates to the sum of persons who are at risk of poverty after social transfers, who are severely materially deprived or living in households with very low work intensity. Persons are considered to be at risk of poverty if they have a disposable income below the risk-ofpoverty threshold, which is set at $60 \%$ of the national median disposable income.

At risk of poverty rate measures the share of persons who are employed and have a disposable income below the risk-of-poverty threshold. A person is considered as being employed if he was employed for more than half of the reference year.

Municipal Waste by Waste Management Operations includes wastes produced by households and other sources such as offices, commerce, and public institutions and collected by or on behalf of municipal authorities and disposed of through the waste management system.

The Share of Energy from Renewable Sources is constructed on energy statistics data, which cover all major sectors of the economy, such as energy sector, industrial sector, commercial and public services, transport, agricultural, forestry, and fishing.

Intramural R\&D Expenditure involves all spending for R\&D performed within a statistical unit or sector of the economy during a specified period. 
Employment in Technology and Knowledge-intensive Sectors at the national level consists of economic, employment and science, technology and innovation data describing industries of manufacturing and services or products broken down by technological intensity. When we cannot find a linear causal relationship between variables, the classification method can provide enough information to link certain datasets to each other. The problem of classification answers the question: if there were predictor values for new observations obtained, can these determine to which classes those observations will belong?

With the aim at getting information required for the analysis, the k-mean method, MatLab algorithm, was selected for clustering the data on aging and sustainable development. This method is used in order to find out the correlations and associations between data fields (Bansal et al. 2017). k-means clustering aims to group $n$ observations into $\mathrm{k}$ clusters thus each observation belongs to the cluster with the nearest mean. The k-means algorithm consists of two steps:

- each observation is assigned to a cluster the mean of which has the least squared Euclidean distance;

- new means of the observations in the new clusters are calculated.

In order to investigate the relationships between aging and different indicators of sustainability, the decision tree method, MatLab algorithm, was selected. This powerful statistical tool is using variable detection, assesses the relative importance of variables, detects the missing values, makes predictions, interpretations, and data manipulations (Song, Ying, 2015). Classification trees consist of next structures: leaves represent class labels and branches represent conjunctions of features that form those class labels. Each branch represents the outcome of a test and each leaf (or terminal) node holds a class label. The decision tree is the predictive model that connects observations about a dataset (represented in the branches) and conclusions about the target dataset (represented in the leaves).

\section{Results of Investigation}

Aging. Aging of EU countries was measured by measuring the median of each country population during the period from 2000 to 2018. In 2000, the median of less than 35 years was in Ireland, Cyprus, Slovakia, and Romania and did not reach 40 years in all countries. In 2018, the median age of these populations was between 37.3 and 46.3 years. (Fig. 1)

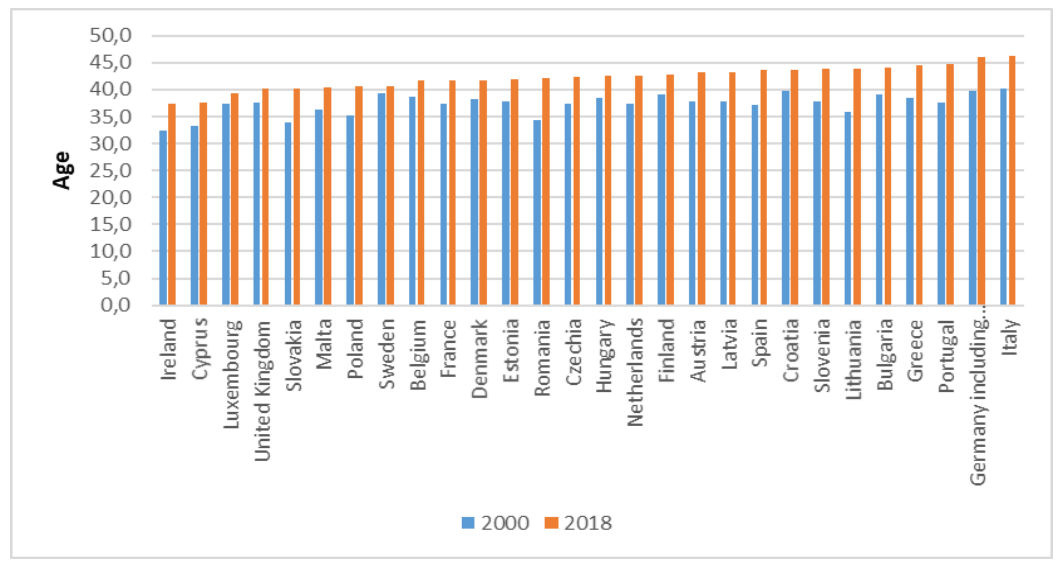

Fig. 1. Age median of EU countries population between 2000 and 2018 (created by authors according Eurostat (2019)) 
Investigation of the aging growth rate in each country revealed very big differences between countries (Fig.2). Small changes (3-7 \%) in aging were found in Sweden, Luxembourg, United Kingdom, and Belgium. These countries are well developed with old family traditions. The biggest changes in the aging growth rate were found in Lithuania $(23 \%)$ and Romania $(22 \%)$ - post-Soviet countries that have a very high level of emigration. Alongside is Portugal, Slovakia, and Spain, but in this case, to name the reason is not that simple.

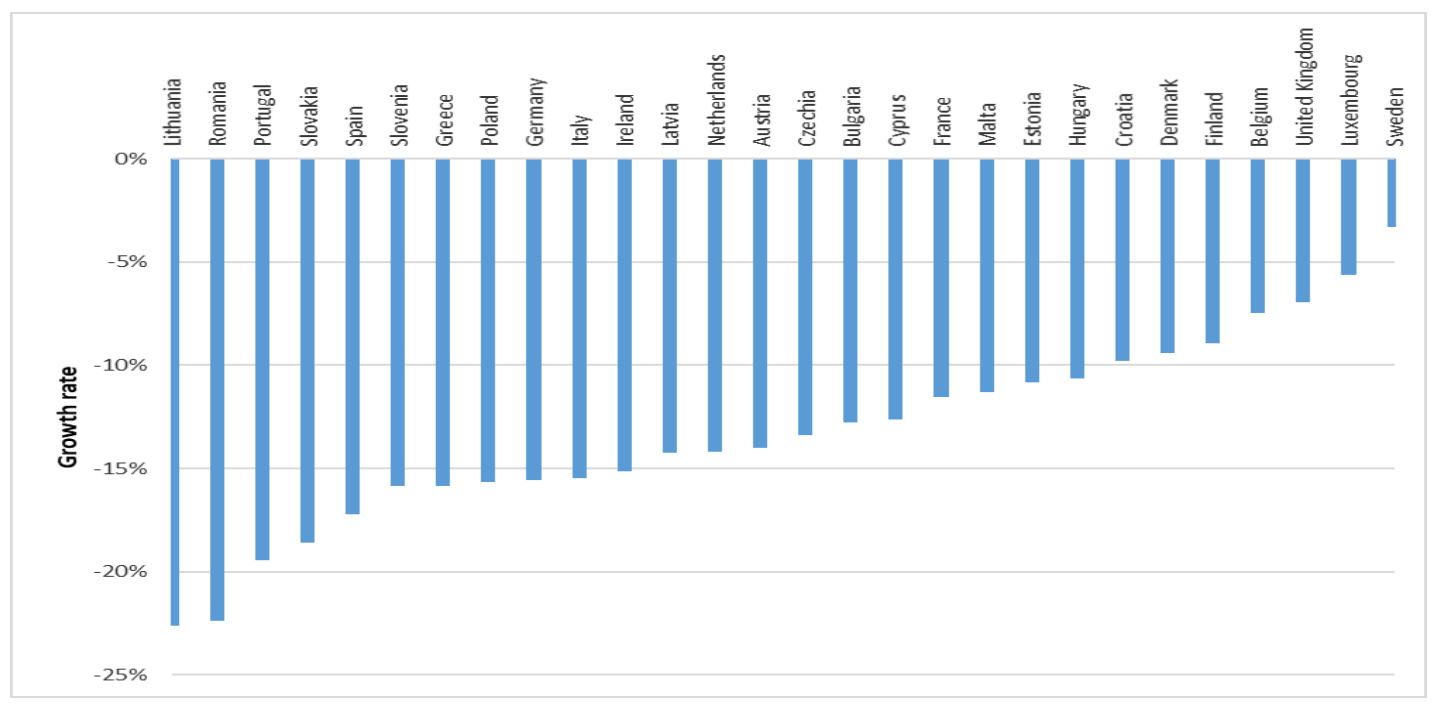

Fig. 2. Age median growth rate of EU countries population between 2000 and 2018 (created by authors according Eurostat (2019))

How does aging relate to sustainable development and does it affect the achievement of the EU's sustainable development objectives? Perhaps certain changes to the phenomena of sustainable development are related to the growth rate of aging.

Aging and indicators of sustainable development. The relation between aging and three groups of indicators of sustainable development of EU countries: social capacity, environmental capacity, and economic capacity, was investigated by the k-mean classification algorithm. The percentage growth rate of people at risk of poverty or social exclusion was selected as a measure reflecting changes to a social capacity in the country. This classification shows that declining poverty rates are typical for countries with high to moderate aging rates and increasing poverty rates (positive) are more likely in countries with medium to low aging rates (Fig. 3). 


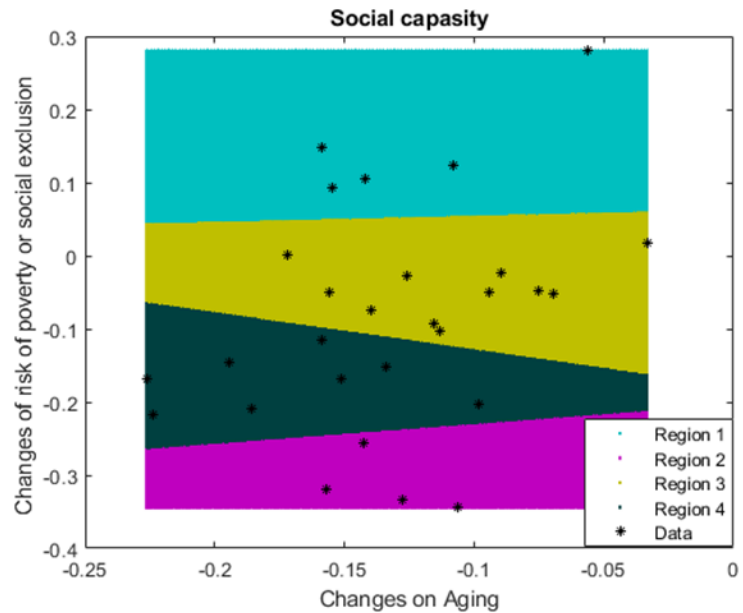

Fig. 3. The percentage change in people at risk of poverty or social exclusion in all EU countries in relation to aging changes (created by authors)

Classification of the growth rate of variable In-work at risk of poverty according to growth rate of aging detected four layers (Fig. 4). The high rate of poverty among working people is linked to the high rate of aging. A small increase in poverty is found across the entire scale of aging. The low rate of poverty reduction is associated with a moderate rate of aging. Meanwhile, the high rate of poverty reduction among the working population is associated with a moderate to low aging rate.

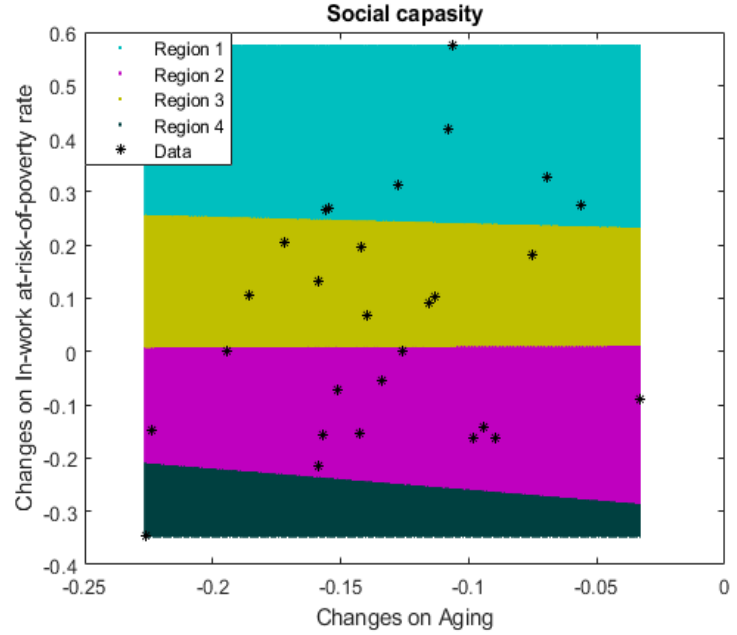

Fig. 4. In-work at-risk-of-poverty rate changes in all EU countries in relation to aging changes (created by authors)

The investigation of the environmental capacity of sustainable development includes the Municipal Waste by Waste Management Operations and the Share of Energy from Renewable Sources. Municipal waste is mainly produced by households and small commerce and public organizations. Classification excludes four countries with very low aging rates and near-zero growth rate of municipal waste due to waste management operations (Fig. 5). The remaining countries are divided into three layers. The large increase in municipal waste is associated with a moderate to high rate of aging. Very many countries have close to zero municipal waste changes and average aging rates. Countries with a clearly increasing municipal waste have moderate to high aging rates. 


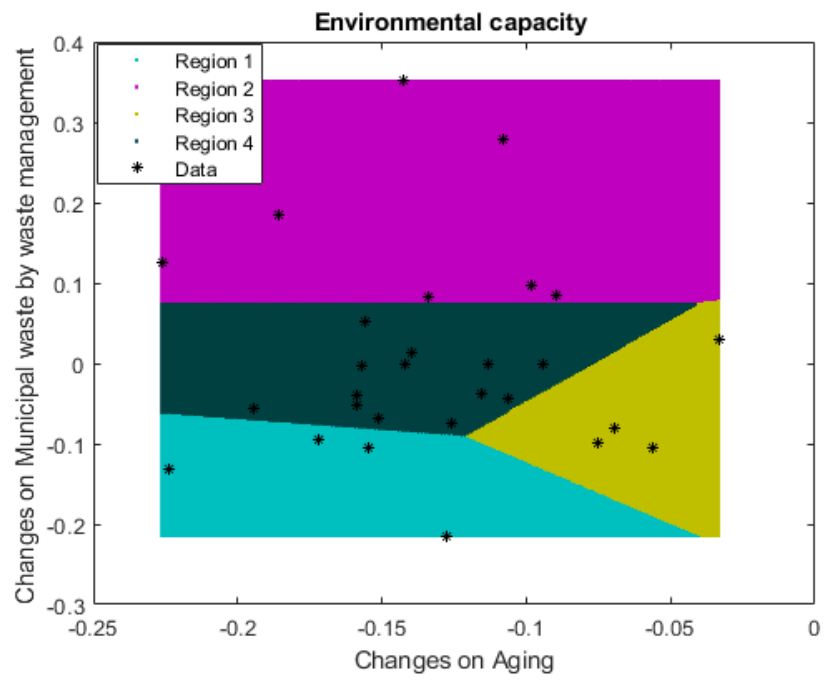

Fig. 5. Changes in Municipal Waste by Waste Management Operations in all EU countries in relation to aging changes (created by authors)

Changes in Share of Energy from Renewable Sources are positive for all countries (Fig. 6). Malta stands out very strongly with a growth rate of 6. United Kingdom and Luxembourg also have strong renewable energy growth of 1.77 and 1.23 respectively. The rate of change in five other countries ranged from 0.60 to 0.84 , while the remaining others ranged from 0.06 to 0.40 . In most countries, indicators are scattered across the entire scale of aging.

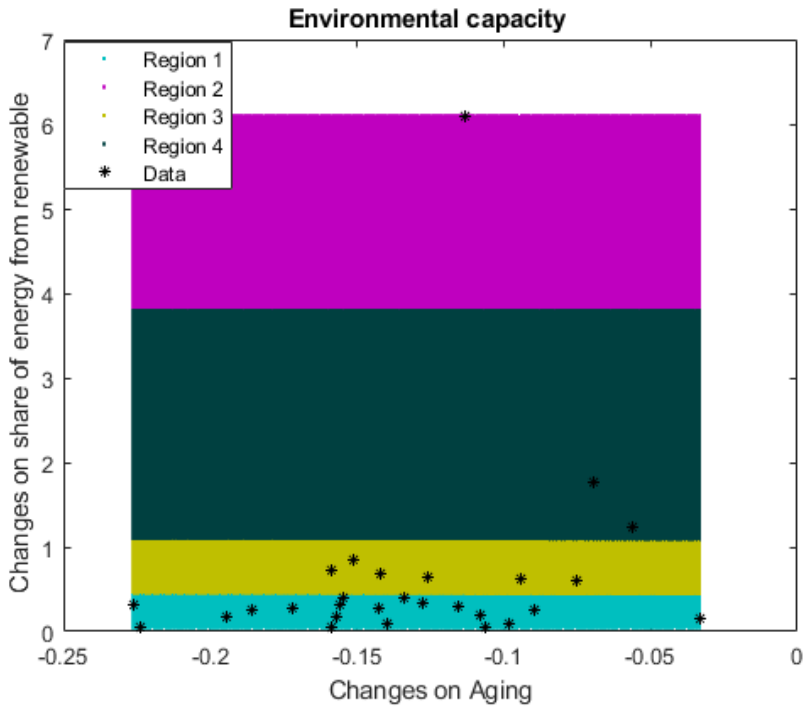

Fig. 6. Changes in Share of Energy from Renewable Sources in all EU countries in relation to aging changes (created by authors)

Finland (-0.14), Spain (-0.04), Portugal (-0.04), and Luxembourg (-0.02) have decreasing R\&D expenditure, while other countries - increasing. Countries with little positive or negative change in this indicator are scattered across the entire aging scale (Fig. 7). Countries with an increase in R\&D expenditure of around 0.2 to 0.4 have moderate or low aging growth, while countries in the range of 0.4 to 0.65 - only moderate. Bulgaria (0.89), Lithuania (0.88), Poland (0.86), Slovakia (0.78), and Romania (0.71) have fast R\&D spending growth and rapid aging. 


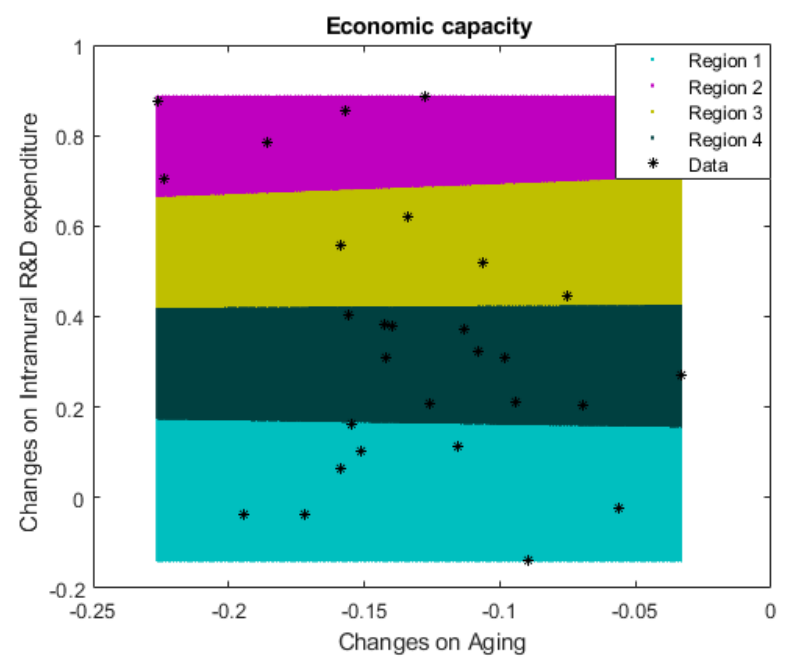

Fig. 7. Changes in Intramural R\&D Expenditure in all EU countries in relation to aging changes (created byauthors)

Denmark (-0.04), Germany (-0.02), and Finland (-0.02) have decreasing Employment in Technology and Knowledge-intensive Sectors at the national level, other countries - increasing. Small negative and positive interval $(-0.04 ; 0.1)$ of this indicator is divided into two regions according to aging changes - less than -0.14 and more than -0.14 . When the indicator is in the range $(0.1 ; 0.4)$, the aging indicators are scattered across the entire scale of the aging indicator. And when the score is greater than 0.4 , the aging rate is moderate to high.

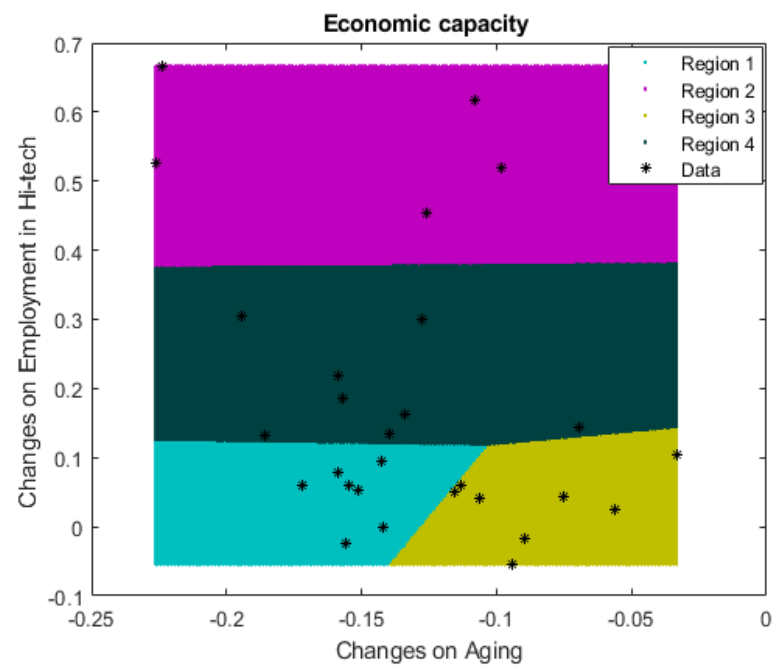

Fig. 8. Changes in Employment in Technology and Knowledge-intensive Sectors at the national level in all EU countries in relation to aging changes (created by authors)

The study shows that there is no strong causal link between the rate of aging and sustainable development. Most regions in the classification are layered, and data shifts of greater or lesser extent are present in those layers. However, two indicators have well-defined regions, dividing the aging scale into low and high values. Classification by Changes in Municipal Waste by Waste Management Operations indicator excludes countries with very low aging rates and near-zero growth rate of Municipal Waste by Waste Management Operations. 


\section{ENTREPRENEURSHIP AND SUSTAINABILITY ISSUES}

ISSN 2345-0282 (online) http://jssidoi.org/jesi/

2020 Volume 7 Number 3 (March)

http://doi.org/10.9770/jesi.2020.7.3(39)

Classification by Employment in Technology and Knowledge-intensive Sectors at the national level indicator is divided into two regions of moderate and small aging changes.

Classification of sustainable indicator groups with valuation growth of aging. In order to find relations between three groups of indicators of sustainable development of EU countries: social capacity, environmental capacity, and economic capacity, there was a classification tree method used. The aging rate in the EU countries ranges from 3 to 23 percent over the period of 2000-2018. The study found that the aging rate is significant if it is 3 times or more lowest than the lowest aging rate (Sweden 3\%). The category assigned to a significant rate of aging is denoted as 1 and the non-significant - as 0 .

Social capacity is represented by these indicators: changes in the percent of people at risk of poverty or social exclusion (work) and changes in the In-work at-risk-of-poverty rate (poverty). For presentation purposes, the classification tree algorithm has selected 4 classes (Fig. 9). When the "work" indicator is bigger than 0.32, the rate of aging is not significant. The ability to make a living from work leads to a lower rate of aging. When the "work" indicator is smaller than 0.32 and the "poverty" indicator is smaller than -0.109 - the aging changing rate is significant. The inability to survive from work leads to a higher rate of aging. When "poverty" is bigger than 0.109 and "work" is between 0.1889 and 0.32 , then aging changes are significant. This suggests that there may be more causes of aging than only poverty.

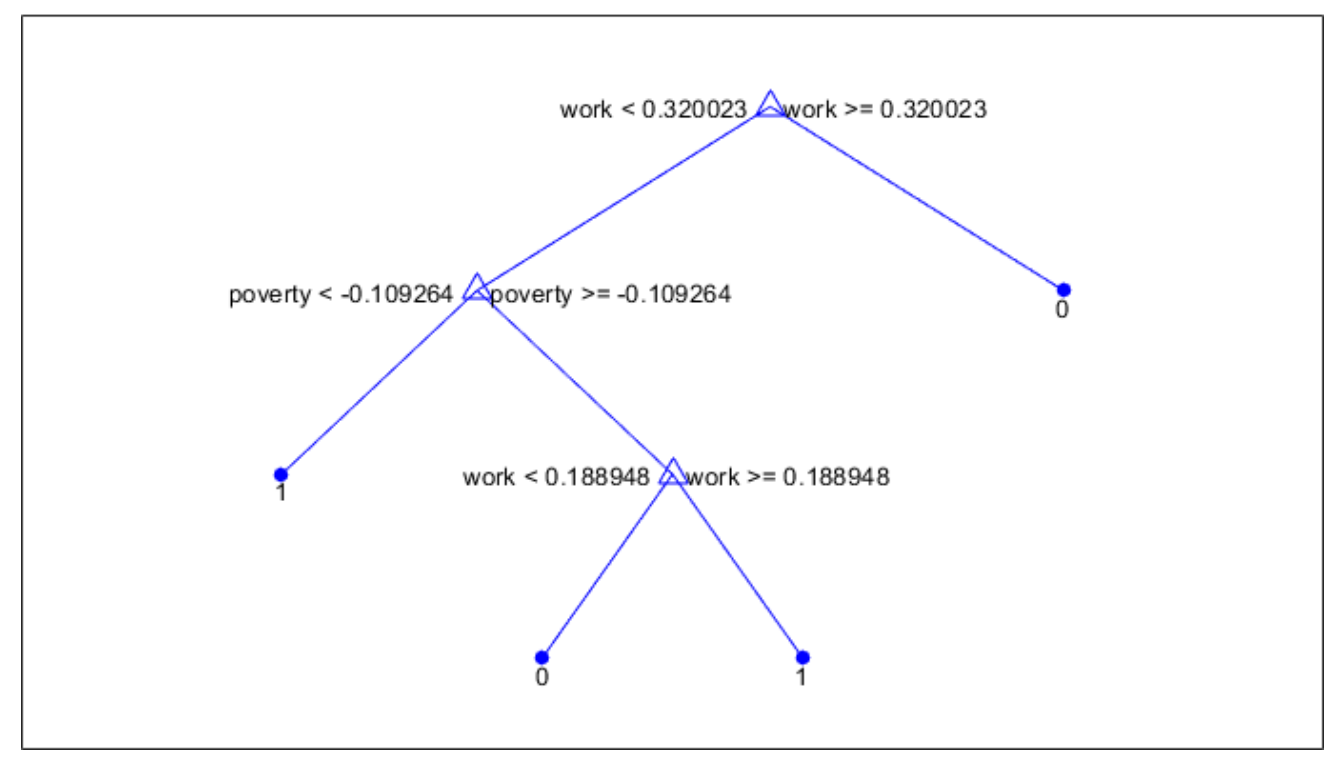

Fig. 9. Intervals of social capacity indicators in relation to aging changes (created by authors)

Environmental capacity is represented by indicators: changes in the Municipal Waste by Waste Management (waste) and changes in the Share of Energy from Renewable Sources (energy) (Fig. 10). The Classification tree algorithm selected two classes with useful accuracy. Low Aging growth can be found only when changes in the Share of Energy from Renewable Sources is bigger than 1.03. Only three countries have this range: Malta, the United Kingdom, and Luxembourg. 


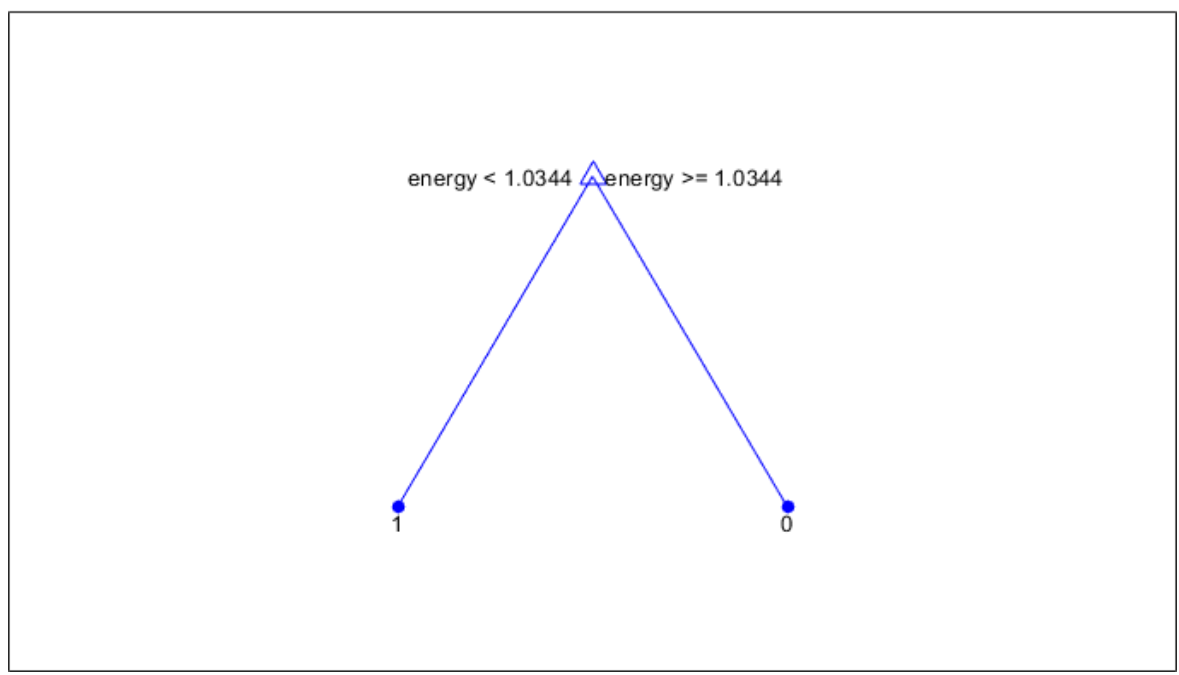

Fig. 10. Intervals in environmental capacity indicators in relation to aging changes (created by authors)

Economic capacity is represented by the indicators that highly impact the economic growth: changes in the Intramural R\&D Expenditure (R\&D) and changes in the Employment in Technology and Knowledge-intensive Sectors at the national level (hi-tech) (11 Fig). For presentation purposes, the Classification algorithm has selected 4 classes. When R\&D is bigger than 0.538 , changes in aging are significant. Countries that are sharply increasing their R\&D spending, have problems with rapid aging. When R\&D is smaller than 0.538 and hi-tech is less than 0.0516, the aging rate is not significant. Countries with low levels of R\&D and high-tech human resources have low aging rates. When hi-tech is more than 0.05 and $R \& D$ is less than 0.182 , aging rate is significant. Countries where the number of people working in the high-tech field is rapidly growing and the expenditure on R\&D is growing very slowly - has a high rate of aging.

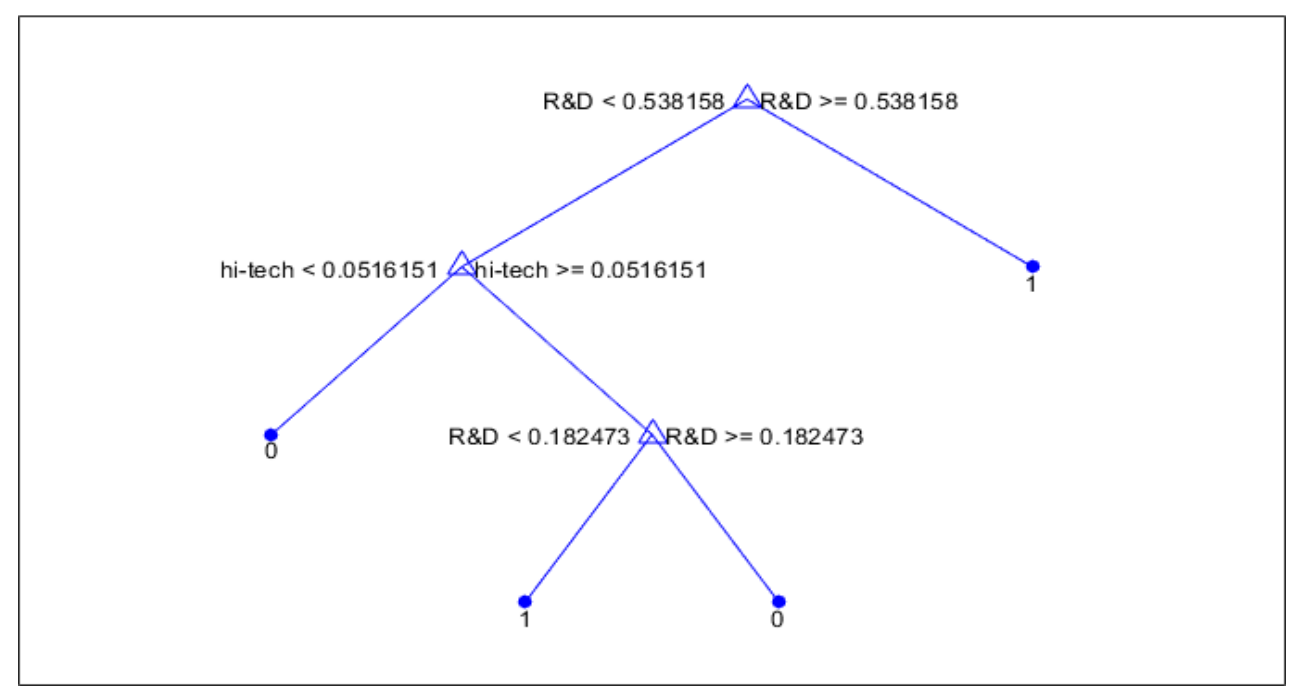

Fig. 11. Intervals of economical capacity indicators in relation to aging changes (created by authors)

The categorization of aging revealed the influence of groups of sustainability indicators in the rate of aging. Social capacity and economical capacity indicators have a relation to aging growth. Investigation of environmental capacity revealed the impact from only one indicator - changes in Share of Energy from Renewable Sources. 
Accuracy of classification (errors). Linear discriminant analysis (lda) and quadratic discriminant analysis (qda) were used to evaluate the accuracy of classification. Cross-validation (CV) divides the training set into 10 random disjoint subsets. Remove one subset, train the classification model using the other nine subsets, and use the trained model to classify the removed subset. K-fold cross-validation partition consists of:

- number of observations - 28 ,

- number of test sets - 10 ;

- train size: 26252525252525252526 ;

- test size: 2333333332 .

Table 3. Errors of classification

\begin{tabular}{|l|r|r|r|}
\hline \multicolumn{1}{|c|}{ Error } & \multicolumn{1}{c|}{ Social capacity } & Environmental capacity & Economic capacity \\
\hline ldaCVErr & 0.4286 & 0.3929 & 0.4286 \\
\hline qdaCVErr & 0.5357 & 0.3571 & 0.6071 \\
\hline dtResubErr & 0.1786 & 0.1786 & 0.1786 \\
\hline dtCVErr & 0.4643 & 0.6429 & 0.5714 \\
\hline ans & 0.3929 & 0.3214 & 0.3929 \\
\hline
\end{tabular}

Errors of classification are presented in Table 3. The true test error for lda using 10-fold stratified crossvalidation is signed by IdaCVErr, and for qda is signed QdaCVErr. Resubstitution error and the cross-validation error for decision tree (dt) is signed as dtResurbErr and dtCVErr, respectively. The final estimated misclassification error is signed as ans.

\section{Conclusions}

Demographical statistical data of EU countries show that the median age of the population of each country in 2000 was between 32.4 and 40.1 while in 2018 - between 37.3 and 46.3. Aging growth rate for the same year interval varies from $3 \%$ to $23 \%$. As a result, the countries of the European Union are aging, and some of them are aging very fast.

K-mean classification algorithm was used for investigation of relations between the aging growth rate and the growth rate of six indicators that meet the Sustainable Development Goals of EU. Percent of people at risk of poverty or social exclusion and In-work at-risk-of-poverty rate represents the social capacity, Municipal Waste by Waste Management Operations and Share of Energy from Renewable Sources represent the environmental capacity, Intramural R\&D Expenditure and Employment in Technology and Knowledge-intensive Sectors at the national level represent the economic capacity. Most regions in the classification are layered; this means that indicators are distributed across the aging scale and in many cases, no causal relationship was found. However, two indicators have well-defined regions dividing the aging scale into low and high values: changes in Municipal Waste by Waste Management Operations and changes in Employment in Technology and Knowledge-intensive Sectors at the national level. The growth rate of these indicators can be linked to a causal relationship with the growth rate of aging.

Classification tree method was used to investigate relations between aging and some tree groups of indicators of sustainable development of EU countries: social capacity, environmental capacity and, economic capacity. The investigation of indicators of social capacity, like Percent of people at risk of poverty or social exclusion and In- 


\section{ENTREPRENEURSHIP AND SUSTAINABILITY ISSUES}

ISSN 2345-0282 (online) http://jssidoi.org/jesi/ 2020 Volume 7 Number 3 (March)

http://doi.org/10.9770/jesi.2020.7.3(39)

work at-risk-of-poverty rate, revealed that the ability to make a living from work is related to a lower rate of aging and the inability to survive from work is related to a higher rate of aging. The classification by environmental capacity indicators - changes in Municipal Waste by Waste Management (waste) and changes in the Share of Energy from Renewable Sources (energy) - split the data into two classes: Share of Energy from Renewable Sources is less than 1.03 and more. The latter may be associated with a higher growth rate of aging. The classification tree of economical capacity growth rate indicators according to the aging rate consist of four classes. Investigation revealed that countries that are sharply increasing their R\&D spending have problems with rapid aging. Countries where people working in the high-tech field is rapidly growing and the expenditure on $\mathrm{R} \& \mathrm{D}$ is growing very slowly - has a high rate of aging. The study shows that the link between aging and sustainable development of EU countries exists even though it is not expressed in a linear causal relationship.

\section{References}

Allen, C.; Nejdawi, R.; El-Baba, J.; Hamati, K.; Metternicht, G.; \& Wiedmann, T. 2017. Indicator-based assessments of progress towards the sustainable development goals (SDGs): a case study from the Arab region. Sustainability Science, 12(6): 975-989. https://doi.org/10.1007/s11625-017-0437-1

Athukorala, P. \& Narayanan, S. 2018. Economic corridors and regional development: the Malaysian experience, World Development, 106: 1-14. https://doi.org/10.1016/j.worlddev.2018.01.009

Atienza, M.; Lufin, M.; \& Soto, J. 2018. Mining linkages in the Chilean copper supply network and regional economic development. Resources Policy, 1-11. https://doi.org/10.1016/j.resourpol.2018.02.013

Baltgailis, J. 2019. The issues of increasing the effectiveness of teaching comparative economics. Insights into Regional Development 1(3): 190-199. https://doi.org/10.9770/ird.2019.1.3(1)

Bansal, A.; Sharma, M.; \& Goel, S. 2017. Improved k-mean clustering algorithm for prediction analysis using classification technique in data mining. International Journal of Computer Applications, 157(6): 0975-8887

Bartelmus, P. 2010. Use and usefulness of sustainability economics. Ecological Economics, 69: 2053-2055. doi:10.1016/j.ecolecon.2010.06.019

Bartniczak, B.; \& Raszkowski, A. 2019. Sustainable development in African countries: an indicator-based approach and recommendations for the future. Sustainability, 11(1): 1-23. https://doi.org/10.3390/su11010022

Baumgärtner, S.; \& Quaas, M. 2010. What is sustainability economics? Ecological Economics, 69: 445-450. https://doi.org/10.1016/j.ecolecon.2009.11.019

Bell, S.; \& Morse, S. 2001. Breaking through the glass ceiling: who really cares about sustainability indicators? Local Environment, 6(3): 291-309.

Binder, M.; \& Witt, U. 2012. A critical note on the role of the capability approach for sustainability economics. The Journal of SocioEconomics, 41: 721-725. http://dx.doi.org/10.1016/j.socec.2012.07.007

Birkin, F.; \& Polesie, T. 2013. The relevance of epistemic analysis to sustainability economics and the capability approach. Ecological Economics, 89: 144-152. http://dx.doi.org/10.1016/j.ecolecon.2013.02.005

Blum, H.; \& Legey, L. F. L. 2012. The challenging economics of energy security: Ensuring energy benefits in support to sustainable development. Energy Economics, 34: 1982-1989. http://dx.doi.org/10.1016/j.eneco.2012.08.013

Bradley, P. 2019. Integrating sustainable development into economics curriculum: a case study analysis and sector wide survey of barriers. Journal of Cleaner Production, 209: 333-352. https://doi.org/10.1016/j.jclepro.2018.10.184

Brundtland, G. 1987. Brundtland Relatory. Our Common Future, United Nations. 


\section{ENTREPRENEURSHIP AND SUSTAINABILITY ISSUES}

ISSN 2345-0282 (online) http://jssidoi.org/jesi/ 2020 Volume 7 Number 3 (March)

http://doi.org/10.9770/jesi.2020.7.3(39)

Chaple, K.; \& Montero, S. 2016. From learning to fragile governance: Regional economic development in rural Peru. Journal of Rural Studies, 44: 143-152. https://doi.org/10.1016/j.jrurstud.2016.01.009

Chapman, A.; \& Shigetomi, Y. 2018. Developing national frameworks for inclusive sustainable development incorporating lifestyle factor importance. Journal of Cleaner Production, 200: 39-47. https://doi.org/10.1016/j.jclepro.2018.07.302

Clark, de Wodrow, W. 2018. Sustainable Cities and Communities Design Handbook: Green Engineering, Architecture, and Technology. Second Edition. Butterworth-Heinemann is an imprint of Elsevier

Cowell, M. M. 2013. Bounce back or move on: Regional resilience and economic development planning. Cities, 30: 212-222. https://doi.org/10.1016/j.cities.2012.04.001

Daniels, P. L. 2010. Climate change, economics and Buddhism - Part 2: New views and practices for sustainable world economies. Ecological Economics, 69: 962-972. https://doi.org/10.1016/j.ecolecon.2010.01.012

Dobrovolskienė, N.; Tamošiūnienė, R.; Banaitis, A.; Ferreira, F.; Banaitienė, N.; Taujanskaite, K.; \& Meidute-Kavaliauskiene, I. 2019. Developing a Composite Sustainability Index for Real Estate Projects using Multiple Criteria Decision Making. Operational Research, 19(3): 617-635, https://doi.org/10.1007/s12351-017-0365-y

Dudzevičiūtè, G. 2015. Ekonomikos plètros pagrindai [Fundations of Economic Development]. Vilnius: Generolo Jono žemaičio Lietuvos karo akademija.

Dugarova, E.: \& Gülasan, N. 2017. Global Trends: Challenges and Opportunities in the Implementation of the Sustainable Development Goals. Joint report by the United Nations Development Programme and the United Nations Research Institute for Social Development. New York: UNDP and Geneva: UNRISD

Estêvão, R. S. G.; Ferreira, F. A. F.; Rosa. A. A.; Govindan, K.; \& Meidute-Kavaliauskienè, I. 2019. A Socio-technical approach to the assessment of sustainable tourism: Adding value with a comprehensive process-oriented framework. Journal of Cleaner Production, 236: 111. https://doi.org/10.1016/j.jclepro.2019.06.318

Eustachio, J. H. P. P.; Ferreira Caldana, A. C.: Liboni, A. B.; \& Martinelli, D. P. 2019. Systemic indicator of sustainable development: Proposal and application of a framework, Journal of Cleaner Production, 241: 118383. https://doi.org/10.1016/j.jclepro.2019.118383

Funar, S.; Curea, C.; \& Ionescu, C. 2009. Managing sustainable development in the European Union. Developments and approaches, 12(2): $1-9$.

Jiang, X.; He, X.; Zhang, L.; Qin, H.; \& Shao, F. 2017. Multimodal transportation infrastructure investment and regional economic development: a structural equation modeling empirical analysis in China from 1986 to 2011. Transport Policy, 54: 43-52. https://doi.org/10.1016/j.tranpol.2016.11.004

Kiely, K. M.; Brady, B.; \& Byles, J. 2019. Gender, mental health and aging. Maturitas 129: 76-84. https://doi.org/10.1016/j.maturitas.2019.09.004

Leeson, G. W. (2019). The aging and de-institutionalisation of death-Evidence from England and Wales. Health Policy 123: 435-439. https://doi.org/10.1016/j.healthpol.2019.01.013

Lejano, R. P.; \& Stokols, D. 2013. Social ecology, sustainability, and economics. Ecological Economics, 89: 1-6. http://dx.doi.org/10.1016/j.ecolecon.2013.01.011

Liboni, L.B.; \& Cezarino, L.O. 2014. Strategy for sustainability in a Brazilian sugarcane industry. World Journal of Entrepreneurship, Management and Sustainable Development, 10(1): 2-12. https://doi.org/10.1108/WJEMSD-02-2013-0018

Lihtmaa, L.; Hess, D. B.; \& Leetmaa, K. 2018. Intersection of the global climate agenda with regional development: unequal distribution of energy efficiency-based renovation subsidies for apartment buildings. Energy Policy, 119: 327-338. https://doi.org/10.1016/j.enpol.2018.04.013

Lund, H.; \& Hvelplund, F. 2012. The economic crisis and sustainable development: the design of job creation strategies by use of concrete institutional economics. Energy, 43:192-200. doi:10.1016/j.energy.2012.02.075 


\section{ENTREPRENEURSHIP AND SUSTAINABILITY ISSUES}

ISSN 2345-0282 (online) http://jssidoi.org/jesi/ 2020 Volume 7 Number 3 (March)

http://doi.org/10.9770/jesi.2020.7.3(39)

Maknickienė N.; Lapinskaitė I.; Miečinskienè A.; \& Skačkauskienė I. 2018. Patterns of inequality of Lithuanian regions. Journal of Business Economics and Management, 19(2): 323-342

Mauerhofer, V. 2019. Legal institutions and ecological economics: their common contribution for achieving a sustainable development. Ecological Economics, 156: 350-359. https://doi.org/10.1016/j.ecolecon.2018.09.023

Moumen, Z., El Idrissi, N.E.A., Tvaronavičienė, M., Lahrach, A. 2019. Water security and sustainable development. Insights into Regional Development, 1(4), 301-317. https://doi.org/10.9770/ird.2019.1.4(2)

Nogueira, Ch. 2019. Contradictions in the concept of sustainable development: an analysis in social, economic, and political contexts, Environmental Development, 30: 129-135. https://doi.org/10.1016/j.envdev.2019.04.004

Pereira, I. P. C.; Ferreira, F. A. F.; Pereira, L. F.; Govindan; K., Meidute-Kavaliauskiene I.; \& Correia, R. J. C. 2020. A Fuzzy Cognitive Mapping-System Dynamics approach to energy-change Impacts on the sustainability of small and medium-sized enterprises. Journal of Cleaner Production, 256: 1-17, doi:10.1016/j.jclepro.2020.120154

Prakash, R.; Garg, P. 2019. Comparative assessment of HDI with Composite Development Index (CDI). Insights into Regional Development 1(1): 58-76. https://doi.org/10.9770/ird.2019.1.1(5)

Reis, I. F. C.; Ferreira, F. A. F.; Meidutè-Kavaliauskienè, I.; Govindan, K.; Fang, W.; \& Falcão, P. F. 2019. An Evaluation Thermometer for Assessing City Sustainability and livability, Journal of Cleaner Production, 47, https://doi.org/10.1016/j.scs.2019.101449

Remig, M. C. 2015. Unraveling the veil of fuzziness: a thick description of sustainability economics. Ecological Economics, 109: 194-202. http://dx.doi.org/10.1016/j.ecolecon.2014.11.016

Sarma, U.; Karnitis, G.; Zuters, J.; Karnitis, E. 2019. District heating networks: enhancement of the efficiency. Insights into Regional Development 1(3): 200-213. https://doi.org/10.9770/ird.2019.1.3(2)

Song, Y. Y.; \& Ying, L. U. 2015. Decision tree methods: applications for classification and prediction. Shanghai archives of psychiatry, 27(2): 130

Stankevičienė J.; Sviderskė T.; \& Miečinskienė A. 2014 Dependence of sustainability on country risk indicators in EU Baltic Sea region countries. Journal of Business Economics and Management, 15(4): 646-663.

Todaro, M. P.; \& Smith, S. C. 2011. Economic development. Eleventh edition. Pearson Education Limited.

United Nations Development Programme. 2017. Aging, older persons and the 2030 agenda for sustainable development. https://www.undp.org/content/undp/en/home/librarypage/poverty-reduction/aging--older-persons-and-the-2030-agenda-for-sustainabledevelo.html

United Nations, Eurostat, International Monetary Fund, Organization for Economic Cooperation and Development and World Bank. 2003. Handbook of National Accounting. Integrated Environmental and Economic Accounting 2003. United Nations publications Series F, n 61, rev1, New York

Vigliarolo, F. 2020. Economic phenomenology: fundamentals, principles and definition. Insights into Regional Development, 2(1), 418429. http://doi.org/10.9770/IRD.2020.2.1(2)

Vokoun, M. 2016. The economics and politics of process innovation and the sustainable urban development, Procedia Engineering, 161: 2229-2233.

World Bank Group. 2016. Global Monitoring Report 2015/2016: Development Goals in an Era of Demographic Change. Washington, DC: World Bank

World Health organization. 2015. World Report on Aging and Health. https://www.who.int/aging/publications/world-report-2015/en/ 


\section{ENTREPRENEURSHIP AND SUSTAINABILITY ISSUES}

ISSN 2345-0282 (online) http://jssidoi.org/jesi/

2020 Volume 7 Number 3 (March)

http://doi.org/10.9770/jesi.2020.7.3(39)

\section{FUNDING}

This work was partially supported by the Ministry of National Defence of the Republic of Lithuania

Ieva MEIDUTE-KAVALIAUSKIENE is a Chief Reasearcher at General Jonas Zemaitis military academy of Lithuania. She holds a PhD in Technological Sciences (Transport engineering) from Vilnius Gediminas Technical University. She has about 15 years lectures experience (taught such courses as logistic, transport management, supply chain management, warehouse logistics and operations management). Her research interests are related to logistics and supply chain management, formation and evaluation of strategic decisions, decision making. She is an author of more than 50 scientific publications indexed in Web of Science, Scopus, Ebsco, Emerald, and other databases, published several monographs and textbooks. The scientific impact of prof. Meidute-Kavaliauskienė in: ResearchGate 27, ISI WoS h-Index 10, Scopus h-Index 10. She is a member of the scientific committees of several scientific journals and international scientific conferences.

ORCID ID: orcid.org/0000-0003-0435-7632

Gitana DUDZEVIČIŪTÉ is an associate professor of General Jonas Žemaitis Military Academy of Lithuania, Department of Strategic Management. Research interests: sustainable development, economic growth and its determinants, defence economics.

Gitanos ORCID ID: orcid.org/0000-0002-4891-224X

Nijolè MAKNICKIENÉ is an associate professor at the Department of Finance Engineering at Vilnius Gediminas technical university. She holds a PhD in social sciences, economics. Research interests - economic forecasting, behavioural finance, investment portfolio as an instrument for resource allocation application in various areas of the economy, artificial intelligence application on forecasting and management of economic processes.

ORCHID ID: orcid.org/0000-0003-2785-5183

Aidas VASILIS VASILIAUSKAS is a Professor of Study and Research Management group at General Jonas Zemaitis military academy of Lithuania. He holds a PhD in Technological Sciences (Transport engineering) from Vilnius Gediminas Technical University. He has about 20 years teaching experience (taught such courses as Transport system, Freight transportation technologies, Logistics). His research interests are related to Transportation, Logistics and Supply chain management. He is an author of around 30 scientific publications indexed in Web of Science, Scopus, Ebsco, Emerald, and other databases, published several monographs and textbooks.

ORCID ID: orcid.org/0000-0002-4547-3966

Copyright (C) 2020 by author(s) and VsI Entrepreneurship and Sustainability Center

This work is licensed under the Creative Commons Attribution International License (CC BY).

http://creativecommons.org/licenses/by/4.0/

(c) (i) Open Access 